\title{
Adverse Event Modified Reported Term
}

National Cancer Institute

\section{Source}

National Cancer Institute. Adverse Event Modified Reported Term. NCI Thesaurus. Code C83206.

An indication or description of a change in an adverse event. 